\title{
Headphone use and anxiety
}

\author{
Kulaklık kullanımı ve anksiyete
}

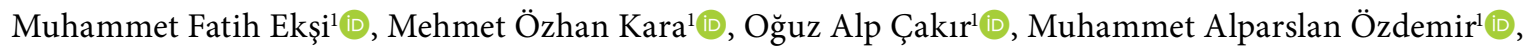 \\ Ali Kaan Akyüz ${ }^{1}$ D, Zehra Pınar Cengiz ${ }^{1}$ D , Muhammet İhsan Çakan ${ }^{1}$ D, Ahmet Selim Keleş ${ }^{1}$, \\ Sercan Obay ${ }^{1}$ (D), Oytun Erbaş ${ }^{2}$, \\ ${ }^{1}$ Biruni University Medical School, Istanbul, Turkey \\ ${ }^{2}$ Department of Physiology, Istanbul Bilim University Faculty of Medicine, Istanbul, Turkey
}

\begin{abstract}
Objectives: This study investigates the relationship between anxiety and headphone use.

Materials and methods: The study was conducted on 180 (54 males, 126 females) undergraduate students. Headphone habits were assessed with a questionnaire, and anxiety levels were assessed with Beck Anxiety Inventory.

Results: While there was no correlation between total anxiety scores and length of headphone use, there was a correlation with purpose of headphone use. There was a positive correlation between headphone use while using a computer $(p<0.05)$, watching media, isolation from the environment, and while studying $(p<0.01)$, as well as a positive correlation with headphone use in evening hours $(p<0.05)$. According to the Beck scale, participants with scores between $26-63$ had high anxiety levels and were positively correlated with headphone use in the evenings, headphone use at school, and when watching media $(\mathrm{p}<0.05)$.

Conclusion: Our study, which aimed to investigate the relationship between headphone habits and anxiety, may inspire and guide further studies on this subject.
\end{abstract}

Keywords: Anxiety, computer, headphones.

\section{ÖZ}

Amaç: Bu çalışmada anksiyete ve kulaklık kullanım alışkanlıkları ve süreleri arasında ilişki araştırıldı.

Gereç ve yöntemler: Çalışma 180 (54 erkek, 126 kız) lisans öğrencisi üzerinde yürütüldü. Kulaklık alışkanlıkları bir anket ile, anksiyete düzeyleri ise Beck Anksiyete Envanteri ile değerlendirildi.

Bulgular: Anksiyete toplam skoru ile kulaklık kullanım süresi arasında ilişki bulunmazken, kulaklığın kullanım amacı arasında ilişki bulundu. Kulaklığın bilgisayar ile kullanımı ( $p<0.05)$, bir şeyler izlerken kullanımı, ortamdan soyutlanmak için kullanımı ve ders çalışırken kullanımı ( $p<0.01)$ arasında pozitif ilişki saptanmış olup gün içinde ve akşam saatlerinde kullanımı $(p<0.05)$ arasında da pozitif ilişki bulundu. Beck skalasına göre $26-63$ puan arasında anksiyete düzeyi yüksek katılımcılarda akşam kulaklık kullanımı, okulda kulaklık kullanımı ve birşeyler izlemek için kulaklık kullanımı ( $p<0.05$ ) arasında pozitif ilişki bulundu.

Sonuç: Sonuç olarak kulaklık kullanım alışkanlıkları ile anksiyete arasındaki ilişki hakkında daha önce yeterince araştırma olmaması yeni araştırmalar için ilham ve kaynak da olabilecektir.

Anahtar sözcükler: Anksiyete, bilgisayar, kulaklık.

Humans are organisms that receive stimuli from the external world throughout the day with sensory organs. These stimuli are the main effectors of human emotion, thought, and decision-making centers. Sound is one of these effectors which give meaning to visual images and emotions in daily life. Recent developments in technology have made mobile phones,

Received: July 11, 2019 Accepted: July 30, 2019 Published online: October 31, 2019

Correspondence: Muhammet Fatih Ekşi. Biruni Üniversitesi Tıp Fakültesi, 34010 Topkapı, İstanbul, Türkiye. Tel: +90 536-6968526 e-mail: muhammetfatiheksi97@gmail.com 
computers, and music players into sources of sound through speakers and headphones. Headphones, which have undisputable importance in sound transmission, have come to play an important role in affecting daily life, from emotion to habits. Unlike speakers, the proximity of headphones is as close to as being a part of the body, and have allowed a more isolated sound transmission to a more specific region. They have also allowed better focus and understanding of the sound. ${ }^{[1]}$ With these advantages, there is a significant increase in headphone use in recent years. A study from Sweden found that $97 \%$ of young people listen to music with headphones and $80 \%$ spend 0.5-2 hours a day with headphones. ${ }^{[2]}$ This degree of exposure of the ear to such stimuli has brought with it the ear disorder tinnitus. ${ }^{[3]}$

The indispensable daily use of headphones has not only affected ear health but also emotional state. Studies have shown that individuals who play video games based on horror and suspense have higher levels of excitement and fear when playing with headphones compared to playing without headphones. ${ }^{[4]}$ Another study on anxiety, defined as the feeling of fear and worry that cannot be overcome according to the American Depression and Anxiety Association, found that use of headphones to block the saw sounds when removing casts lowered anxiety levels in children. ${ }^{[5]}$

Therefore, it is undeniable that increased headphone use in daily life may affect ear health and even emotional state. In this study, a questionnaire and the Beck Anxiety Inventory ${ }^{[6]}$ were applied to investigate headphone habits and purposes in Biruni University students and whether or not there was relationship with anxiety levels.

\section{MATERIALS AND METHODS}

This study was conducted between 03/27/2018-06/01/2018 at Biruni University. The study sample consisted of 180 (54 males, 126 females) Biruni University students. Since one of the participants did not fully complete the questionnaire, 179 participants were analyzed. The study was conducted by administering a questionnaire within the campus. In order to prevent bias and protect privacy of information, names of participants were not collected in the questionnaire.

The questionnaire consisted of three sections and 19 questions. The first section covered basic data such as age, gender, and faculty. The second section assessed headphone habits and frequency of use, used devices, and purposes of use in 11 questions. The final section consisted of five questions on individual and familial diseases as well as use of medications of the participants.

Data collection tools were the Beck scale and the questionnaire developed by the authors. The Beck scale results were divided into four separate categories: score of 0-7 minimal anxiety, 8-15 mild anxiety, 16-25 moderate anxiety, and 26-63 severe anxiety. Participants with anxiety scores of 26-63 were recommended consultation with a specialist. Headphone use habits of the people who completed the questionnaire were investigated possible correlation with Beck Anxiety Scale scores was assessed.

The study obtained ethics approval from the Biruni University Noninterventional Research Ethics Committee. Informed written consent was acquired from study participants. The study was conducted in accordance with the principles of the Declaration of Helsinki.

\section{RESULTS}

Data was obtained from the 180 participants (54 males, 126 females) who were undergraduate students studying at Biruni University. Since one student did not fully complete the questionnaire, 179 participants were analyzed. Unequal distribution was due to $71 \%$ of Biruni University

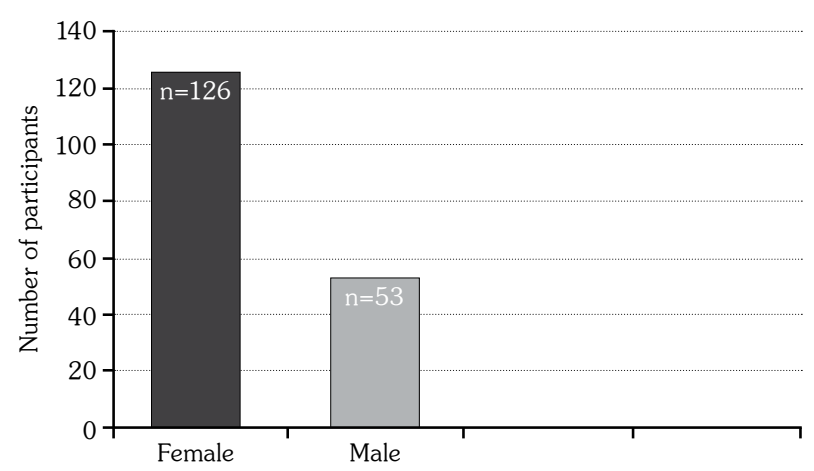

Figure 1. Gender distributions. 


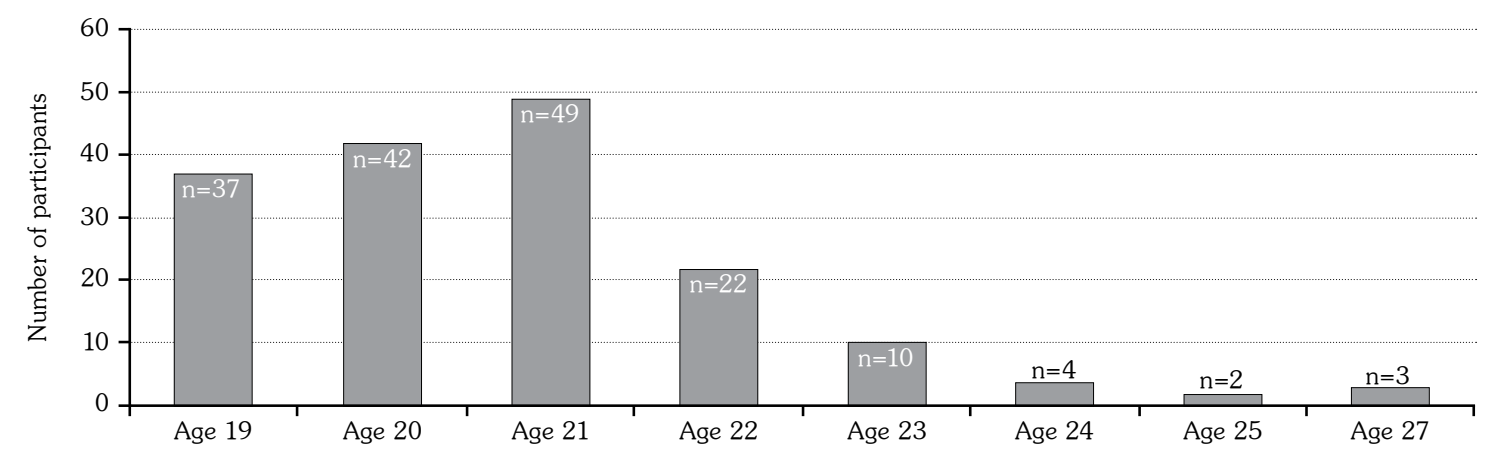

Figure 2. Age distributions.

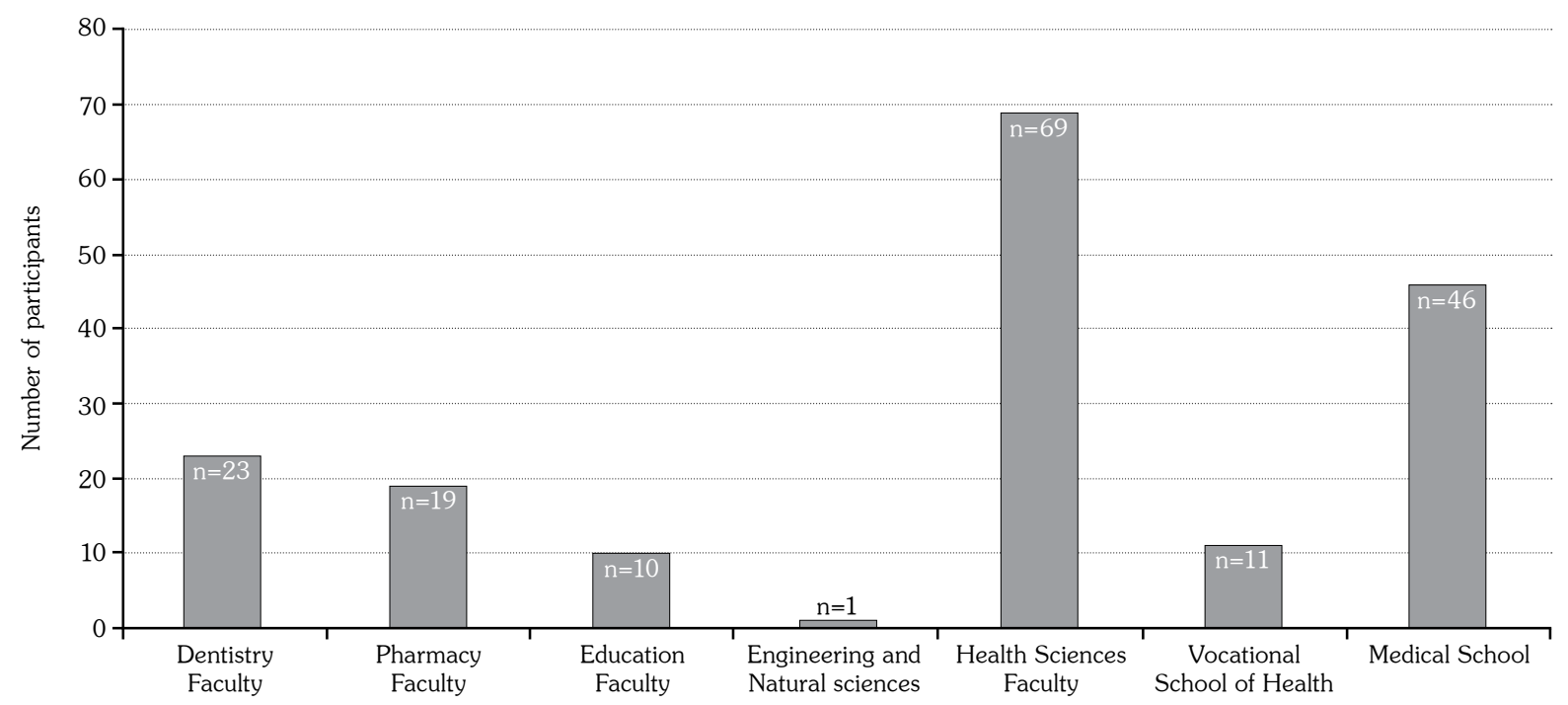

Figure 3. Faculty-based distribution.

students being female, and $70.4 \%$ of the study sample consisted of females (Figure 1). Mean age of the study sample was $21 \pm 1.6$ years (range: 18-27) (Figure 2). While 38.5\% of the sample were students in the Medical Sciences Faculty in which 25.7\% were Medical Faculty students, who comprised the majority of the sample (Figure 3).

The question "How many years have you been using headphones?" was responded with 5-10 years by $42 \%$ of the participants and $1-5$ years by $39.1 \%$ (Figure 4). We believe this length of use is affected by age of the study sample. The question of "How often do you use headphones in a week?" was responded with 6-7 days by $46.9 \%$ of participants, which showed a large majority used headphones at least every day, followed by $21.8 \%$ of participants who used headphones 4-5 days a week (Figure 5,
$6,7)$. The question, "How many hours per day do you use headphones?" was responded as 2-3 hours by $44.7 \%$ and $0-1$ hours by $34.6 \%$ of the study sample (Figure 6, 8, 9). For the multiplechoice question of "Which device do you use your

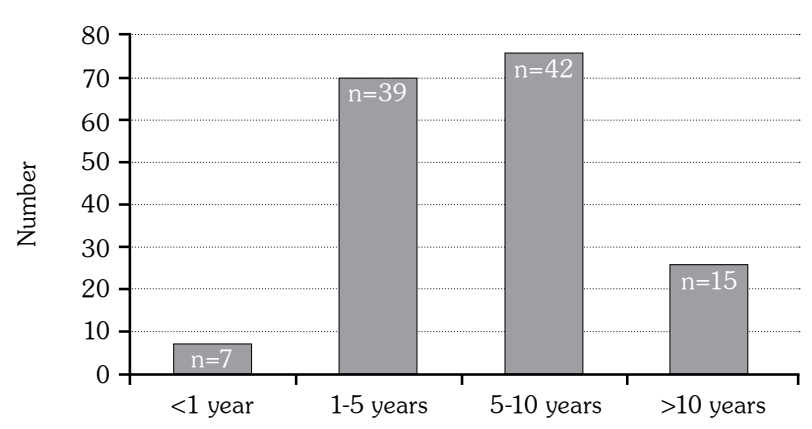

Figure 4. Distribution of headphones use by year. 
headphones with?", 94.4\% responded as cellphone and $46.9 \%$ responded that they used headphones with their computer (Figure 10). The multiplechoice question "What purpose do you use your headphones for?" was responded as "listening to music' by $93 \%$ and 'to watch media' by $65.9 \%$

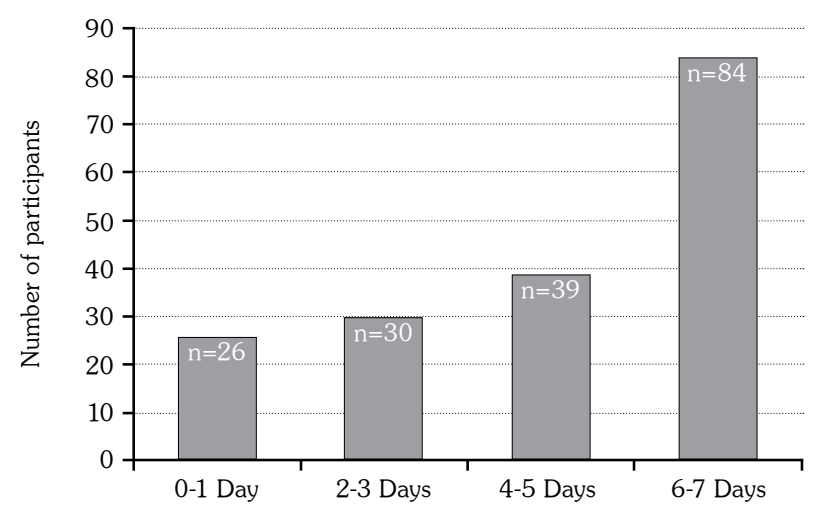

Figure 5. Weekly use of headphones.

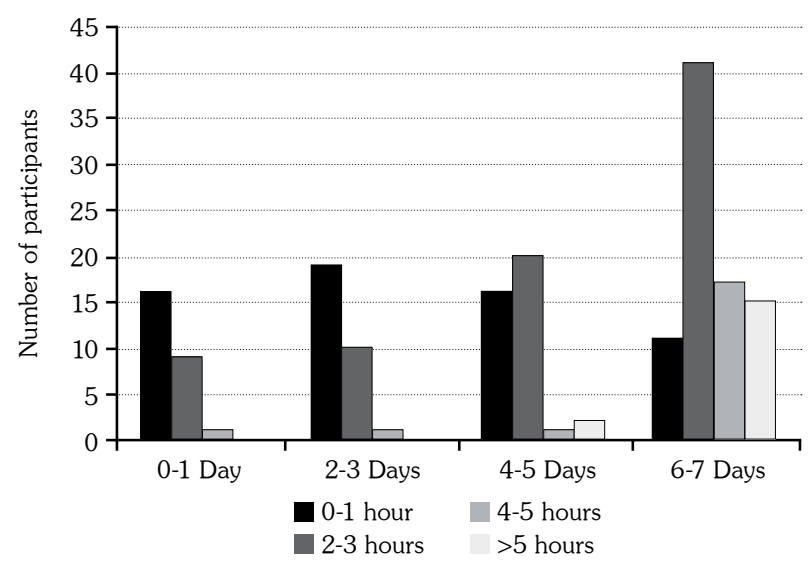

Figure 6. Weekly-daily usage times by number of people.

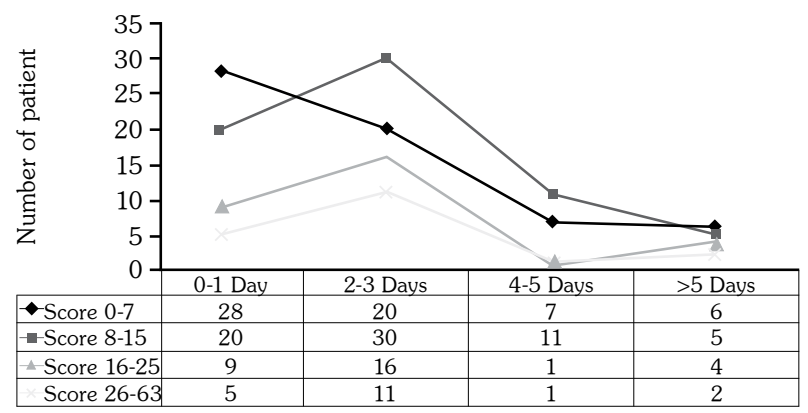

Figure 7. Distribution of anxiety score groups according to daily use. of participants, while 47 participants stated they used headphones to "isolate themselves from the environment' and to 'listen to audio recordings' by eight participants (Figure 11).

The multiple-choice question of "If so, which type of music do you listen to?" was responded as pop as the most popular answer by 138 participants followed by rock music and classical music by

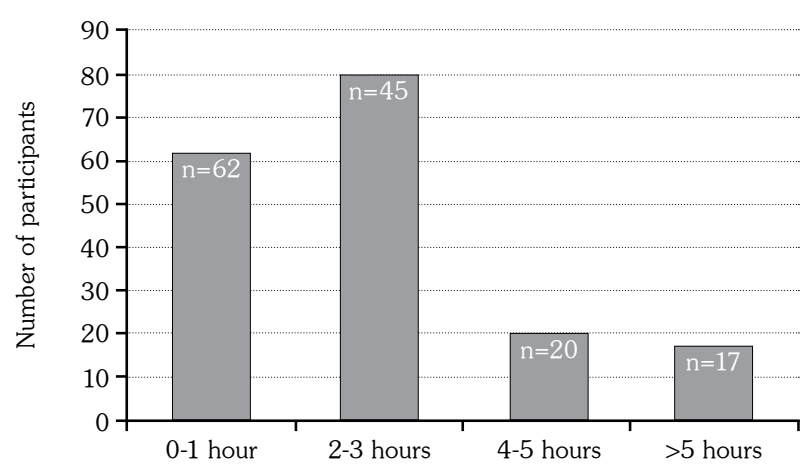

Figure 8. Daily use of headphones.

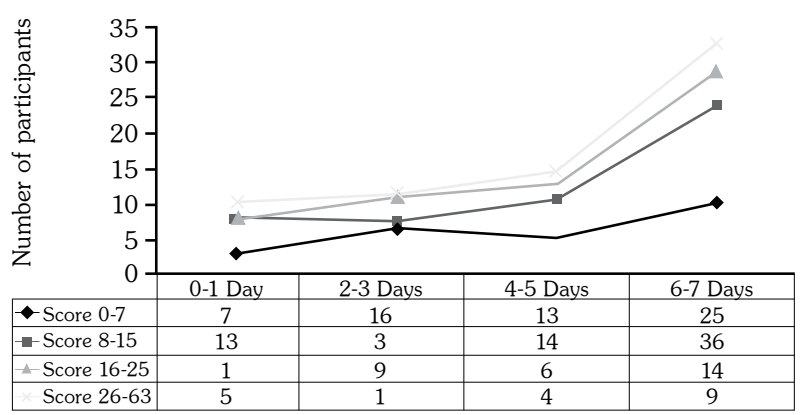

Figure 9. Distribution of anxiety score groups of weekly use.

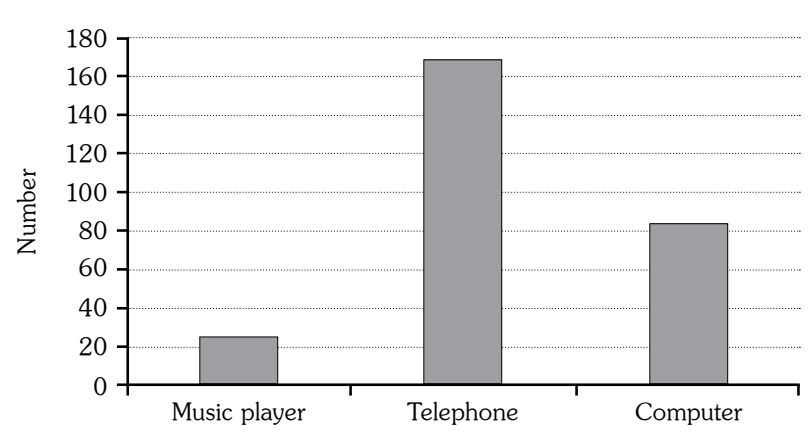

Figure 10. Devices used with headphones. 
70 participants each (Figure 12). The most popular response to the multiple-choice question of "When do you use headphones?" was "during transportation" by 138 participants (Figure 13). The second most popular response was "when relaxing' by 100 people. "What times of the day do you use headphones?" was responded as 'evening' by 114 people as the top response
(Figure 14). In the study sample, 145 participants stated they used in-ear headphones as the most commonly preferred headphone type, in which wired headphones were the most popular type (162). It was observed that $36.3 \%$ of the sample used single headphones. It was observed that $48.6 \%$ of the participants used headphones at moderate sound volume.

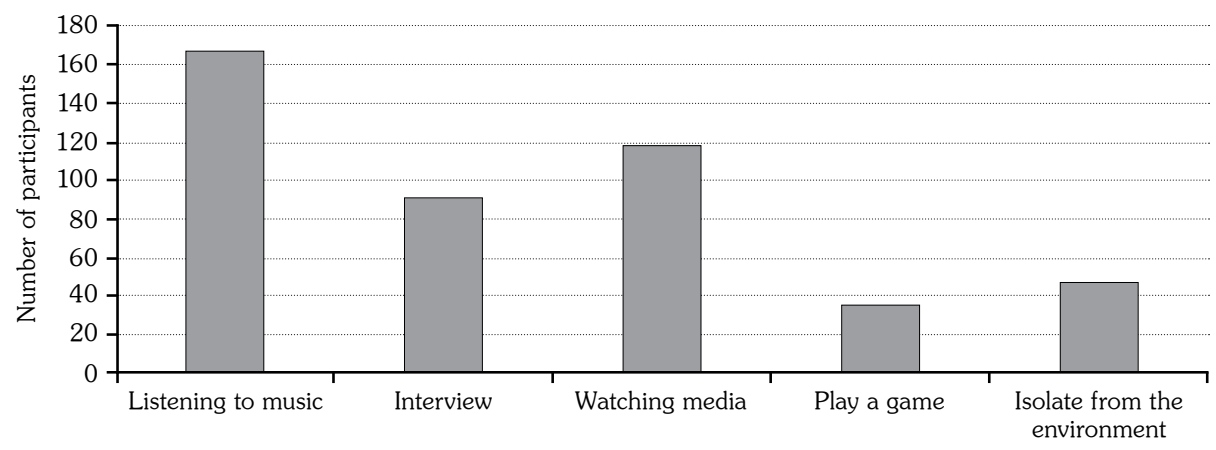

Figure 11. Headphone intended use.

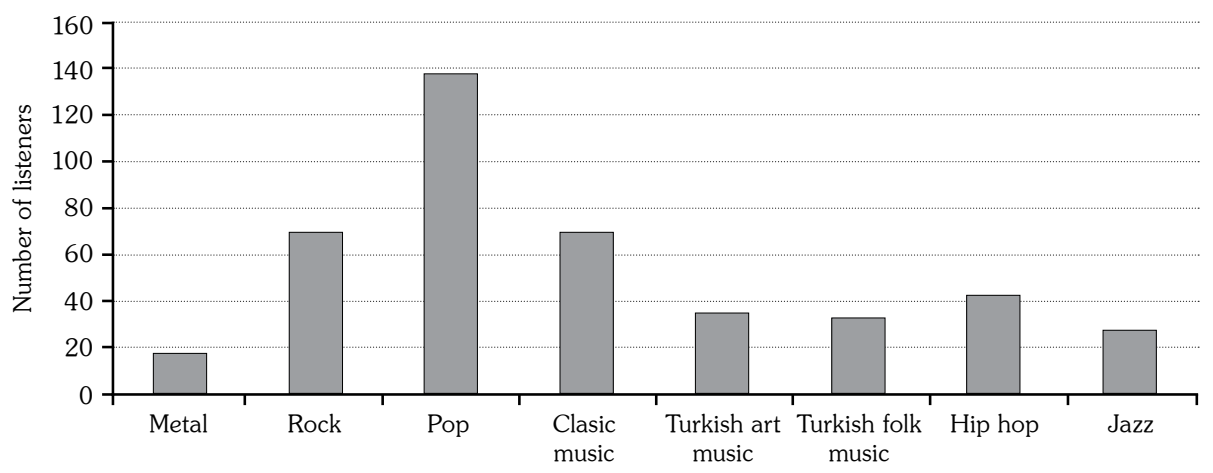

Figure 12. With headphones listening music types.

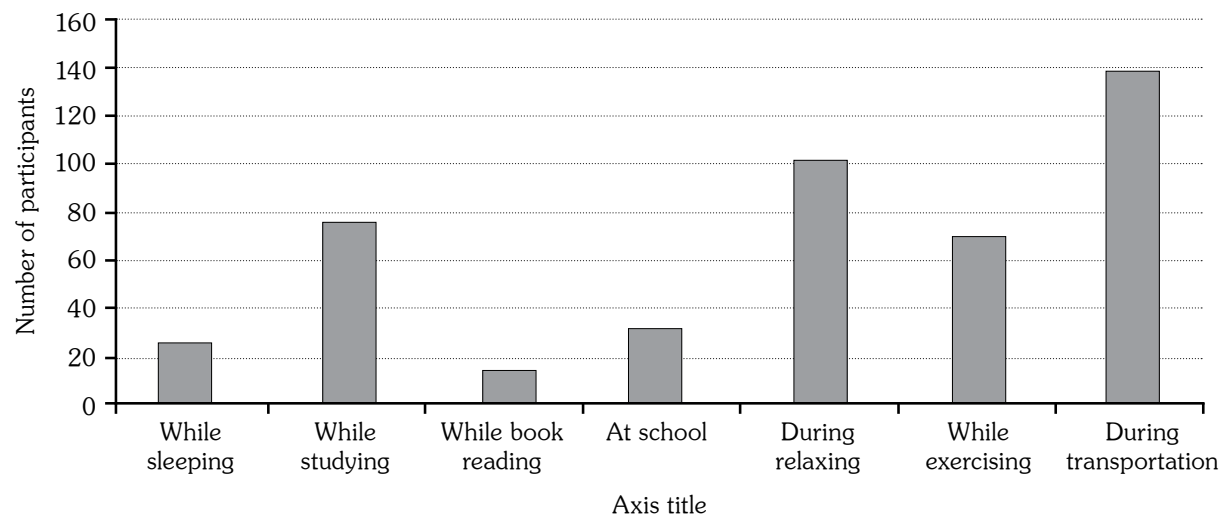

Figure 13. Activities with headphones. 


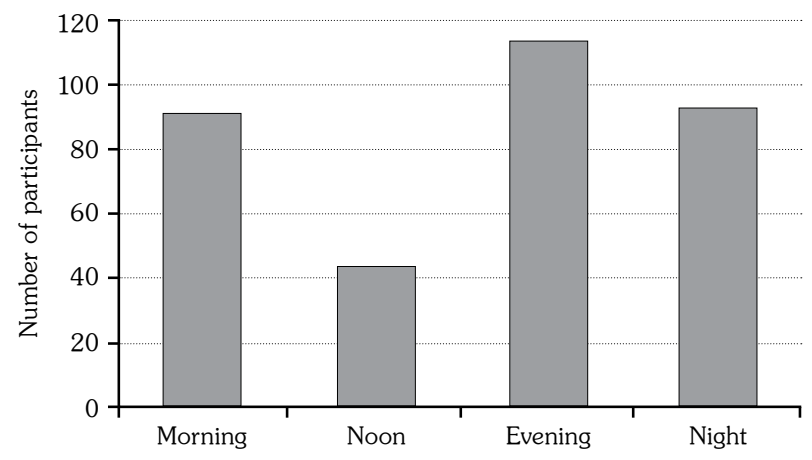

Figure 14. Distribution of headphones by year.

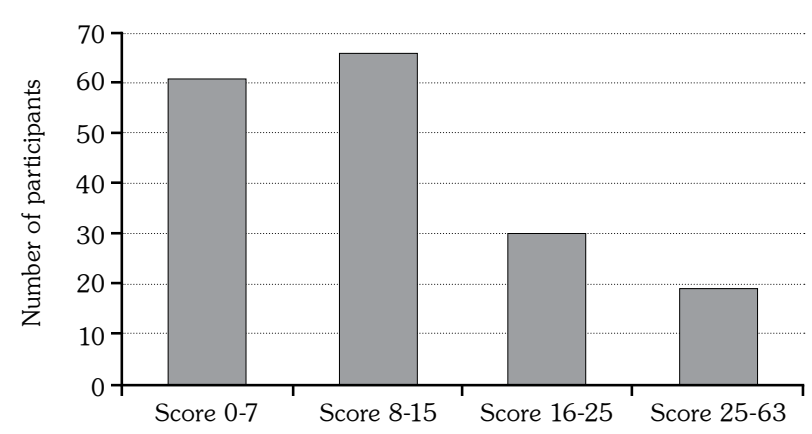

Figure 15. Anxiety score ranges distribution.

Three of the participants had a hearing problem and $28.5 \%$ of the study sample had a family member with a hearing problem. A total of $18.4 \%$ of the participants had problems related to their headphones (pain, itching, feeling of fullness, tinnitus, difficulty hearing, headache, etc.). Two of the participants were found to have an ear condition (one person vertigo, one person Meniere's disease). A total of $7.3 \%$ of the study sample were using medications, which included Cipralex, Levmont, Lithuril, Prozac, Roaccutane, thyroid hormone, and Venotrex.

Mean total anxiety score of the entire study group was $11.97 \pm 9.3$. The lowest score among the participants was 0 and the highest score was 42 . Of the participants, $34 \%$ had score of $0-7$ and $36.9 \%$ 8-15 (Figure 15). A total of $16.8 \%$ of the participants had score between 16-25 and were informed they were at the border range and recommended specialist consultation. The participant with maximum anxiety score (42 points) indicated he/she was undergoing treatment.

\section{DISCUSSION}

Along with depression, anxiety disorders are the most common mental disorders. ${ }^{[7,8]}$ Again, after depression, anxiety disorders are more common among university students and are at higher levels. In addition, the same study indicated that this condition was associated with social factors, family-related factors, and academic stressors. ${ }^{[9]}$ In order to illustrate the possible relationships between headphone use, which is increasingly common with developing technology, this study was conducted to determine headphone use habits and to measure anxiety levels among Biruni University students and to evaluate some of the variables associated with anxiety disorders. This study sample which consists of university students will contribute to evaluation of this problem and provide a data resource for headphone habits and anxiety levels of university students. As the association between these two topics has not been investigated before, this study may inspire and guide further studies on this subject.

A three-section questionnaire and Beck Anxiety Inventory scale was applied to 179 participants. The first section of the questionnaire consisted of demographic data, the second headphone habits, and the third questioned diseases and medications; anxiety scores from the BAI were calculated to correspond to a 0-63 score range.

Of the study sample, $70 \%$ were females and $30 \%$ were males. This is due to the student profile and conditions under which the questionnaire was distributed, because the university only consisted of health majors. In this context, our study sample was not a good representation of university students. Further studies will overcome this issue. This rate was in favor of $60 \%$ female and $51 \%$ male in other studies that investigated the use of headphones in adolescents and young adults.

Age was more homogenously distributed in this study. Of the study participants, $84 \%$ were between the 19-22 age range, while the youngest age was 18 and the oldest was 27, and mean age was 20.63 years. This mean value was 21 years in the other study that encompassed university students. ${ }^{[10]}$ In this university of two-year, fouryear, five-year, and six-year majors, the sample 
was a good representation in context of this data. There was no significant correlation between age and anxiety scores.

Faculty and major of the participants were questioned and it was observed that the study sample was not a good representation of the population. Of the students who participated in the study, $25.7 \%$ were medical faculty students, $37.9 \%$ were health science faculty students, and the remaining $36.4 \%$ represented the remaining four faculties and vocational health science schools. The association between anxiety scores and university majors was not investigated, as this was not the subject of the study.

Times of headphone use was assessed in three question as time of the year, week, and day. While $42 \%$ of participants had been using headphones for 5-10 years, $4 \%$ had been using headphones for less than one year. There is no example of this data from another study. A total of $47 \%$ of participants indicated they used headphones 6-7 days a week. Similar rates were found in other studies that investigated frequency of headphone use as $47 \%^{[10]}$ and $33 \% .^{[11]}$ This shows that about half of the participants use headphones almost every day a week.

While our study found that $69 \%$ of participants used headphones for more than half a week, another study found this rate as 66\%.[11] Daily use of 2-3 hours was found in $45 \%$ of participants, while this rate was $42 \%$ in another study. ${ }^{[10]}$ In yet another study, $80 \%$ of participants used headphones 1-3 hours a day. ${ }^{[12]}$ The rate of those who used headphones for more than five hours a day was 9\% in this study and 11 in another study. Mean weekly use was 3.01 days and mean daily use was 1.96 hours. These rates were found as 6.5 days $^{[13]}$ and 1.5 hours $^{[14]}$ in two other studies, respectively. When all results of the sample were evaluated, it was observed that responses were similar to results of other studies. When durations of use were evaluated under three categories, it was found that amount of use increased with computer use and listening to music $(p<0.01)$. There was no significant correlation between anxiety scores and exposure time, the main focus of our study.

The devices used with headphones was also investigated. The most common device used with headphones was cellphone as 94\% followed by computer in $47 \%$ and music player as $14 \%$. Previous studies found the rate of using headphones with music players as $85 \%[10]$ and 90\%. ${ }^{[15]}$ This decreased rate and increased rate with cellphone use is likely because most smartphones include many features including playing music. According to correlation with anxiety scores, there was a positive correlation with headphone use with computer, and negative correlation with those with minimal anxiety scores of 0-7 $(p<0.05)$.

According to the purpose of use, the most common was to listen to music (93\%), while $65 \%$ used headphones to watch media (65\%), having a conversation (50\%), isolation from the environment (26\%), and playing games (19\%). In those that used headphones to watch media, there was a positive correlation with total score $(p<0.01)$ and high anxiety levels of 26-63 points, and nefative correlation with minimal anxiety scores of $0-7 \quad(p<0.01)$. These results are indicative that those who use headphones to watch media have higher anxiety scores and when combined with the results that those who used headphones with the computer had higher anxiety scores yields a stronger finding, although the accuracy of this finding could be confirmed in further studies.

The types of music listened to by participants was evaluated and the most popular type was pop (77\%) followed by rock and classical music (39\%). The least popular type of music was metal (10\%). The correlation between music types and anxiety scores was not investigated, as it was not the topic of the study.

Headphone use during various activities was also questioned. It was found that $77 \%$ of participants used headphones when using transportation. ${ }^{[10]}$ The same rate was found as $90 \%$ in a study in Sweden. ${ }^{[2]}$ Headphone use while resting was found as 56\%, which was found as $60 \%$ and $25 \%$ in two other studies. ${ }^{[2,10]}$ Use while studying was found as $42 \%$ and use while doing sports was 39\%.

There was no significant correlation between anxiety scores and headphone use during transportation. There was a negative correlation between headphone use while relaxing and minimal anxiety scores of 0-7 $(p<0.05)$. There was a negative correlation between headphone 
use during exercise and minimal anxiety scores of $0-7 \quad(p<0.05)$. This shows us that those who use headphones when exercising or relaxing had higher anxiety scores. In those who used headphones when studying, there was a positive correlation between total score $(p<0.01)$ and moderate anxiety of $16-25$ points $(p<0.05)$. This also suggests that those who use headphones when studying have higher anxiety levels.

The questionnaire also investigated headphone use during certain times of the day. Evening use was $63 \%$ and night use was $51 \%$. It was found that headphones were used more commonly after dark. There was positive correlation between those who used headphones during morning and minimal anxiety scores of 0-7, while there was a positive correlation between nighttime use and high anxiety scores of 26-63 $(p<0.05)$. This also suggests use of headphones after dark is associated with increased anxiety scores.

Headphone types were also investigated. According to the results, $81 \%$ of participants used in-ear headphones. This rate was found as $76 \%$ and $92 \%$ in two other studies. ${ }^{[10,16]}$ Wireless headphone use was 7\% and wired headphone use was 93\%. Correlation between headphone types and anxiety scores was not assessed.

Use of headphones on only one side was also questioned, but the question was not worded correctly and misunderstood by participants, therefore, accurate results could not be obtained.

Another question was about average volume when using headphones. This was questioned with multiple choices as very high, high, medium, low, and very low sound volume. According to results, $48 \%$ used headphones at medium volume and $20 \%$ at high volume. The same rates were reported as 39\% medium volume and 29\% high volume in one study, ${ }^{[10]}$ and total of $90 \%$ as medium and high volume in another study. Only $7 \%$ of participants used headphones at high volume, reported as 6\% in another study. According to the correlation between anxiety scores and sound volumes, there was a negative correlation with moderate anxiety of $16-25$ points $(p<0.01)$. As sound volume increased, moderate anxiety levels were observed less. This was surprising, as the expected result was that anxiety would increase with increased volume.
The final portion of the questionnaire was about ear health. According to data, $1.7 \%$ of participants had any hearing disorder, while $28.5 \%$ of participants had a family member with hearing disorders. Those with hearing disorders or family member with a hearing disorder were found to have ear-related symptoms which was evaluated in the next question. In addition, those with hearing disorders less commonly used in-ear headphones $(p<0.05)$. There was increased rate of moderate anxiety of $16-25$ points in those with a family member with hearing disorders $(\mathrm{p}<0.05)$.

For the question about presence of various recent ear-related symptoms, $81 \%$ responded as no while $19 \%$ said yes. Another study found the presence of ear-related symptoms as 7\%. ${ }^{[2]}$ There was a positive correlation between this question and total scores $(p<0.05)$. There was a negative correlation between results of this question and minimal anxiety score of 0-7 ( $<<0.05)$. In scope of this data, recent onset ear problems seemed to be associated with increased anxiety levels. This shows that anxiety levels are higher in those with certain symptoms.

The next question was about presence of otitis media, otitis externa, Meniere's disease, vertigo, and ear tumor; one patient had Meniere's disease, and two had vertigo. The second part of the same question questioned presence of major depression which may affect anxiety scores; none of the participants had major depression.

The final question of the questionnaire was about routine use of medications, in which 13 participants used various medications.

According to the results of the Beck Anxiety Inventory in order to determine anxiety levels, $35.8 \%$ of participants had minimal anxiety scores of $0-7,37 \%$ had mild anxiety scores of $8-15$, $17 \%$ had moderate anxiety scores of $16-25$, and $11 \%$ had severe anxiety scores of $25-63$. The 19 participants with high anxiety scores were recommended consultation with a specialist. One study on female students found rate of mild and minimal anxiety as $77 \%$, moderate anxiety $20 \%$, and severe anxiety as 3\%. ${ }^{[17]}$ Few studies on anxiety in general have been conducted since the year 2000, and most studies have been on outpatients and university students. ${ }^{[18]}$ However, 
prevalence of anxiety in our country is $17.7 \% .^{[19]}$ One foreign study reported prevalence of anxiety was $13 \%$ among university students. ${ }^{[20]}$ This rate is relatively similar to our rate of $11 \%$. Nevertheless, future studies will provide stronger evidence and correlations.

In conclusion, this study investigated the association between anxiety and headphone use, which has nowadays become an undeniable part of daily life, in students of Biruni University.

According to the results of the questionnaire used in the study and Beck's Anxiety Inventory, there was no significant correlation between total anxiety scores and length of headphone use. However, there was a positive relationship between headphone use while using a computer $(p<0.05)$, watching media, isolation from the environment, and while studying $(p<0.01)$, as well as a positive correlation with headphone use in evening hours $(p<0.05)$. According to the Beck scale, participants with scores between 26-63 had high anxiety levels and there had a positive correlation between headphone use in the evenings, headphone use at school, and when watching media $(p<0.05)$. Another result of the study sample was that females had relatively higher anxiety scores compared to males. Since only three participants had earrelated disorders, as listed above, no assessment was made. Additionally, there was no significant data related to anxiety scores in terms of headphone volume.

Our hypotheses can be confirmed and new findings can be obtained with newer studies with larger study sample. Although there is a limited number of studies on this subject, this study may open the door to new studies on this topic.

\section{Declaration of conflicting interests}

The authors declared no conflicts of interest with respect to the authorship and/or publication of this article.

\section{Funding}

The authors received no financial support for the research and/or authorship of this article.

\section{REFERENCES}

1. Kallinen K, Ravaja N. Comparing speakers versus headphones in listening to news from a computer- individual differences and psychophysiological responses, Comput Human Behav 2007;23:303-17.

2. Widen SE, Båsjö S, Möller C, Kähäri K. Headphone listening habits and hearing thresholds in swedish adolescents. Noise Health 2017;19:125-32.

3. Bulbul SF, Muluk NB, Cakir EP, Tufan E. Subjective tinnitus and hearing problems in adolescents. Int $\mathrm{J}$ Pediatr Otorhinolaryngol 2009;73:1124-31.

4. Riddle K, Di Z, Kim S, Myung E, Tay SK, Xu F. The unexpected comfort of wearing headphones: Emotional and cognitive effects of headphone use when playing a bloody video game. Entertainment Computing 2017;19:43-52.

5. Mahan ST, Harris MS, Lierhaus AM, Miller PE, DiFazio RL. Noise reduction to reduce patient anxiety during cast removal: can we decrease patient anxiety with cast removal by wearing noise reduction headphones during cast saw use? Orthop Nurs 2017;36:271-8.

6. Muntingh AD, van der Feltz-Cornelis CM, van Marwijk HW, Spinhoven P, Penninx BW, van Balkom AJ. Is the beck anxiety inventory a good tool to assess the severity of anxiety? a primary care study in the netherlands study of depression and anxiety (NESDA). BMC Fam Pract 2011;12:66.

7. Kaya M, Genç M, Kaya B, Pehlivan E. Tip Fakültesi ve Sağlık Yüksekokulu öğrencilerinde depresif belirti yaygınlığı, stresle başa çıkma tarzları ve etkileyen faktörler. Türk Psikiyatri Dergisi 2007;18:137-46.

8. Kılıç BG, Şener Ş. Dikkat eksikliği hiperaktivite bozukluğu olan çocuklarda karşıt olma karşı gelme bozukluğu/davranış bozukluğu eș hastalanımında aile işlevleri ve psikososyal değişkenlerin karşılaştırılması. Türk Psikiyatri Dergisi 2007;16:21-8.

9. Balanza Galindo S, Morales Moreno I, Guerrero Muñoz J, Conesa Conesa A. Academic and psychosocio-familiar factors associated to anxiety and depression in university students. Reliability and validity of a questionnaire. Rev Esp Salud Publica 2008;82:189-200.

10. Tanrıkulu N, Şenkal ÖA, Aydın E, Özlüoğlu L, Tekindal MA. The effect of music listening habits of university students via headphones on hearing thresholds: A Başkent University Sample. KBB ve BBC Dergisi 2013;21:93-103.

11. Hoover A, Krishnamurti S. Survey of college students' MP3 listening: Habits, safety issues, attitudes, and education. Am J Audiol 2010;19:73-83.

12. Kim MG, Hong SM, Shim HJ, Kim YD, Cha CI, Yeo SG. Hearing threshold of Korean adolescents associated with the use of personal music players. Yonsei Med J 2009;50:771-6.

13. McNeill K, Keith SE, Feder K, Konkle AT, Michaud DS. MP3 player listening habits of 17 to 23 year old university students. J Acoust Soc Am 2010;128:646-53.

14. Kumar A, Mathew K, Alexander SA, Kiran C. Output sound pressure levels of personal music systems and their effect on hearing. Noise Health 2009;11:132-40. 
15. Vogel I, Verschuure H, van der Ploeg CP, Brug J, Raat H. Adolescents and MP3 players: too many risks, too few precautions. Pediatrics 2009;123:e953-8.

16. Torre P. Young adults' use and output level settings of personal music systems. Ear Hear 2008;29:791-9.

17. Yılmaz M, Ocakçı AF. Bir Kız Öğrenci Yurdunda Kalan Üniversite Öğrencilerinin Anksiyete Düzeylerinin Belirlenmesi. Maltepe Üniversitesi Hemşirelik Bilim ve Sanatı Dergisi 2010;3:15-23.

18. Binbay T, Direk N, Aker T, Akvardar Y, Alptekin $\mathrm{K}$, Cimilli $\mathrm{C}$ ve ark. Türkiye'de psikiyatrik epidemiyoloji: Yakın zamanlı araştırmalarda temel bulgular ve gelecek için öneriler. Türk Psikiyatri Dergisi 2014;25:264-81.

19. Ertan T. Psikiyatrik bozuklukların epidemiyolojisi. Türkiye'de sık karşılaşılan psikiyatrik hastalıklar. Sempozyum Dizisi 2008;62:S25-30.

20. Eisenberg DA, Yu M, Lam CW, Ogunseitan OA, Schoenung JM. Comparative alternative materials assessment to screen toxicity hazards in the life cycle of CIGS thin film photovoltaics. J Hazard Mater 2013;260:534-42. 